Génét. Sél. Evol., 1983, 15 (1), 65-82

\title{
The inheritance of halothane susceptibility in pigs
}

\author{
A.E. CARDEN*, W.G. HILL** and A.J. WEBB \\ A.R.C. Animal Breeding Research Organisation, \\ West Mains Road, Edinburgh EH9 3JQ, U.K. \\ * On leave from E.E.R.A. Pergamino, I.N.T.A., c.c. 3 I, \\ 2700 Pergamino, Buenos Aires, Argentina \\ ** Institute of Animal Genetics, University of Edinburgh, \\ West Mains Road, Edinburgh EH9 $3 J N$, U.K.
}

\begin{abstract}
Summary
The mode of inheritance of the reaction to halothane anaesthesia in pigs was investigated in 40 litters by 14 sires in a Pietrain-Hampshire synthetic population and in 60 litters by 28 sires in a British Landrace experimental herd. The single-recessive mode of inheritance was tested as a hypothesis in the context of (I) a single-locus-two-alleles model where both the heterozygotes and one of the homozygotes react to the anaesthetic and (II) a two-locus model involving a susceptibility locus and a suppressor locus, both assumed to have two alleles. Maximum likelihood techniques were used to fit the models to the data. The results of the single-locus analysis did not disprove the single-recessive hypothesis in Pietrain-Hampshire. The same analysis provided strong evidence to reject a strictly recessive mode of inheritance in British Landrace; the parameter estimates indicated that about a quarter of the heterozgotes were positive reactors after the halothane test. Although not conclusive, the two-locus analysis in Pietrain-Hampshire indicated that the addition of a suppressor locus to a single-recessive model could improve the genetic explanation of halothane testing results. The two-locus analysis also rejected the single-recessive hypothesis as the mode of inheritance of halothane susceptibility in British Landrace pigs.
\end{abstract}

Key-words : Halothane susceptibility, inheritance, pigs.

\section{Résumé}

L'hérédité de la sensibilité à l'halothane chez le porc

Le mode de transmission de la réaction à l'anesthésie à l'halothane a été examiné dans 40 portées issues de 14 verrats dans une population synthétique Piétrain-Hampshire et dans 60 portées issues de 28 verrats dans un troupeau expérimental British Landrace. L'hypothèse monogénique récessive généralement admise a été testée dans le contexte (1) d'un modèle général à un locus biallélique où à la fois les hétérozygotes et un des génotypes homozygotes peuvent réagir à l'anesthésie et (2) d'un modèle à deux locus, impliquant un locus de sensibilité et un locus suppresseur, tous deux à deux allèles. Les techniques du maximum de vraisemblance ont été utilisées pour ajuster les modèles aux données. Les résultats de l'analyse à un locus ne contredisent pas l'hypothèse monogénique récessive dans le cas du Piétrain-Hampshire. La même analyse conduit à un forte présomption de rejet d'un mode de transmission rigoureusement 
récessif dans le British Landrace ; les paramètres estimés indiquent qu'à peu près la moitié des hétérozygotes réagissent positivement à l'halothane. Bien qu'elle ne soit pas concluante, l'analyse à deux locus en Piétrain-Hampshire indique que l'addition d'un locus suppresseur au modèle monogénique récessif pourrait améliorer l'explication génétique des résultats des tests à l'halothane. L'analyse à deux locus conduit aussi à rejeter l'hypothèse monogénique récessive comme mode de transmission de la sensibilité à l'halothane dans le British Landrace.

Mots-clés: Sensibilité à l'halothane, déterminisme génétique, porcins.

\section{Introduction}

Many investigators have concluded that the reaction triggered by the anaesthetic halothane in pigs is a recessive trait controlled by a single autosomal locus (OLLIVIER, Sellier \& Monin, 1975, 1978 : Minkema, Eikflenboom \& van Eldik, 1976 ; Smith \& Bampton, 1977 : McPhee, Takken \& D’Arcy, 1979 ; Mabry, Christian \& Kuhlers, 1981). Other authors have put forward alternative genetic explanations, including singledominant and two-locus modes of inheritance (Jones et al., 1972; WiLliams et al., 1975, 1978 ; BRITT, Kallow \& ENDRENY1, 1978) but have not presented any formal genetic analysis supporting their conclusions. There are no adequate studies as yet in the literature on the relative merits of the single-recessive hypothesis tested under alternative Mendelian models. However, taking into account the contrasting interpretations mentioned above, and considering that the low penetrance values in some studies (e.g. Ollivier et al., 1975, 1978) might indicate a poor description of the events by the single-recessive model, there is a case for more thorough hypothesis testing. This can be particularly informative on data where it is not immediately obvious that a single-recessive mode of inheritance provides the most adequate explanation.

The purpose of this study was to test the validity of the single-recessive hypothesis for mode of inheritance of halothane susceptibility in pigs, within the framework of (I) a single locus model and (II) a model involving two epistatic loci. The models were fitted to data from experimental Pietrain-Hampshire and British Landrace herds by the method of maximum likelihood.

\section{Material and methods}

\section{A. Animals}

Halothane testing results from a synthetic population founded from crosses of Pietrain and Hampshire and a British Landrace experimental population were used in this study. All pigs received one 3-minute halothane test at between 5 and 10 weeks of age as described by WEBB \& JORDAN (1978). Pigs developing a clear rigidity of the hind limbs within the test period were scored as positive reactors; 'the rest were classified as negative reactors.

The Pietrain-Hampshire data were presented by Sмiтн \& BAmpton (1977) who first analysed this material. Briefly, pigs from the third generation of a randomly mated synthetic population containing 40 p. 100 Pietrain and 60 p. 100 Hampshire genes were subjected to the halothane test. The population was subsequently divided 
into two lines by mating mainly reactors with reactors and non-reactors with nonreactors. The offspring from these matings were also halothane tested. In contrast to Smith and Bampton's investigation, only those families with known parental phenotypes were included in the present study. The frequency of positive reactions amongst parents was 0.33 . The testing results are given in the Appendix.

The Landrace data were collected in an experimental population set up by the Animal Breeding Research Organisation (ABRO) after a survey of the incidence of halothane sensitivity in British nucleus herds, which revealed an average frequency of positive reactors of 0.12 for this breed (WEBB, 1980). The animals constituting the parental group were purchased from nine of the surveyed herds after being halothane tested on their original farms. The frequency of positive reactors in this group was 0.48 . Two lines were then formed, mating reactors with reactors and non-reactors with non-reactors. The progeny from these matings were born and halothane tested at ABRO. These data are also shown in the Appendix. The Pietrain-Hampshire and the Landrace herds were kept on different farms.

\section{B. Models}

The single locus recessive (SLR) hypothesis was tested within the framework of a general single-locus model where both the heterozygote and one of the homozygous genotypes were allowed to react to the anaesthetic. The SLR hypothesis was also tested within the framework of a two-locus model involving a "susceptibility " locus and a suppressor locus. The purpose of this model was to explain genetically part of the variation in penetrance as observed under the SLR hopothesis. In all cases two phenotypes were considered : reactor (R) and non-reactor (NR). The models were fitted to the data by the method of maximum likelihood, following Sмітн \& BAMPTON's procedure (1977). This procedure will be described in detail for the single-locus model and outlined for the two-locus model.

\section{(i) Model 1. Single-locus}

The model requires two alleles : $\mathrm{n}$, with frequency $\mathrm{q}$, and $\mathrm{N}$, with frequency $\mathrm{p}$ $(=1-q)$. Mating was at random in the Pietrain-Hampshire population before the subdivision ; therefore, for the parental generation the expected genotypic frequencies and the penetrances are :

\begin{tabular}{ll|c|c|c}
\hline \multirow{2}{*}{} & & \multicolumn{3}{|c}{ Genotype } \\
\cline { 2 - 4 } & & $\mathrm{NN}$ & $\mathrm{Nn}$ & $\mathrm{nn}$ \\
\cline { 2 - 4 } Code (i) $\ldots \ldots \ldots$ & 1 & 2 & 3 \\
Frequency & $\ldots \ldots$ & $\mathrm{p}^{2}$ & $2 \mathrm{pq}$ & $\mathrm{q}^{2}$ \\
Penetrance & $\ldots \ldots$ & 0 & $\mathrm{f}_{1}$ & $\mathrm{f}_{2}$ \\
\hline \hline
\end{tabular}

Some special cases under this model are $f_{1}=f_{2}=1$ (dominant, completely penetrant) and $f_{1}=0, f_{2}=1$ (recessive, completely penetrant). The model does not allow phenocopies. 
The prior joint probabilities of parental phenotypes and genotypes $\left(Q_{i}\right.$ and $\left.Q_{i}^{\prime}\right)$ are :

\begin{tabular}{|c|c|c|}
\hline & \multicolumn{2}{|c|}{ Phenotype } \\
\hline & $\mathbf{R}$ & NR \\
\hline Probability $\ldots .$. & $\mathrm{Q}_{\mathrm{i}}$ & $Q^{\prime}{ }_{i}$ \\
\hline Genotype & & \\
\hline NN $\ldots$ & 0 & $\mathrm{p}^{2}$ \\
\hline $\mathrm{Nn}$ & $2 f_{1} p q$ & $2\left(1-f_{1}\right) p q$ \\
\hline nn $\ldots$ & $f_{2} q^{2}$ & $\left(1-f_{2}\right) q^{2}$ \\
\hline
\end{tabular}

The probabilities of reactions among the progeny of the different matings $\left(P_{i j}\right)$ are conditional on the parental genotypes and are as shown below :

\begin{tabular}{|c|c|c|c|c|}
\hline & & \multicolumn{3}{|c|}{ Sire (i) } \\
\hline & & NN & $\mathrm{Nn}$ & $\mathrm{nn}$ \\
\hline \multirow{3}{*}{ Dam (j) } & NN & 0 & $\mathbf{f}_{1} / 2$ & $f_{1}$ \\
\hline & $\mathrm{Nn}$ & $\mathrm{f}_{1} / 2$ & $\left(2 f_{1}+f_{2}\right) / 4$ & $\left(f_{1}+f_{2}\right) / 2$ \\
\hline & $\mathrm{nn}$ & $f_{1}$ & $\left(f_{1}+f_{2}\right) / 2$ & $\mathrm{f}_{2}$ \\
\hline
\end{tabular}

The joint likelihood for a population with s sires, each mated to a variable number of dams $\mathrm{d}$, is given by :

$$
\begin{aligned}
& L=\prod_{g=1}^{s} \sum_{i=1}^{k}\left\{( Q _ { i } z _ { i } + Q _ { i } ^ { \prime } ( 1 - z _ { i } ) ) \prod _ { h = 1 } ^ { d } \sum _ { j = 1 } ^ { k } \left[\left(Q_{j} z_{j}\right.\right.\right. \\
& \left.\left.\left.+Q^{\prime}{ }_{j}\left(1-z_{j}\right)\right)\left(\begin{array}{l}
N_{i j} \\
R_{i j}
\end{array}\right)\left(P_{i j}\right)^{R_{i j}}\left(1-P_{i j}\right)^{\left(N_{i j}-R_{i j}\right)}\right]\right\} \ldots
\end{aligned}
$$

where $\mathrm{z}=1$ if the parent is a reactor and $\mathrm{z}=0$ if it is a non-reactor, the index $\mathrm{k}$ refers to the number of genotypes in the model, $\mathrm{N}$ is the number of progeny from a particular mating and $R$ is the number of progeny reacting to halothane from that mating. Equation (1) is general and holds for all models in this study. In the present case the likelihood is a function $(\emptyset)$ of three parameters, $L=\emptyset\left(q, f_{1}, f_{2}\right)$.

In Landrace, the parental generation was sampled from the British Landrace nucleus population. Although the frequency of halothane positive reactions in this population was 0.12 (WEBB, 1980), roughly equal numbers of positive and negative reactors were purchased for the foundation generation of the experimental lines. For 
this reason the terms $Q_{i}$ and $Q^{\prime}{ }_{i}$ in equation (1) must now represent the prior probabilities of parental genotypes conditional on phenotype. In contrast to PietrainHampshire, the probabilities $\mathrm{Q}_{i}$ and $\mathrm{Q}^{\prime}{ }_{i}$ are conditional on phenotypes in all the analyses of Landrace data throughout this study.

Also distinct from Pietrain-Hampshire, the parental Landrace group was composed of pigs from nine different herds ; therefore, the expected genotypic frequencies are no longer represented by the Hardy-Weinberg proportions. However, assuming equilibrium holds in the different subpopulations, the expected parental genotypic frequencies are functions of the mean $(q)$ and the variance $\left(V_{q}\right)$ of the gene frequency. Thus, taking these facts into account, if the frequency of halothane positive reactions is given by :

$$
F=2 f_{1}\left(\bar{p} \bar{q}-V_{q}\right)+f_{2}\left(\bar{q}^{2}+V_{q}\right)
$$

the conditional probabilities of parental genotypes for the Single-Locus model in Landrace are :

\begin{tabular}{|c|c|c|}
\hline Genotypes & $Q_{i}$ & $Q^{\prime}{ }_{i}$ \\
\hline NN $\ldots$ & 0 & $\left(\bar{p}^{2}+V_{q}\right) /(1-F)$ \\
\hline $\mathrm{Nn} \ldots \ldots \ldots$ & $2 \mathrm{f}_{1}\left(\overline{\mathrm{p}} \overline{\mathrm{q}}-\mathrm{V}_{\mathrm{q}}\right) / \mathrm{F}$ & $2\left(1-f_{1}\right)\left(\bar{p} \bar{q}-V_{q}\right) /(1-F)$ \\
\hline nn $\ldots$ & $f_{2}\left(\bar{q}^{2}+V_{q}\right) / F$ & $\left(1-f_{2}\right)\left(\bar{q}^{2}+V_{q}\right) /(1-F)$ \\
\hline
\end{tabular}

The joint likelihood is now a function of four parameters : $\bar{q}, V_{q}, f_{1}, f_{2}$. The SLR hypothesis is obtained if the restriction $f_{1}=0$ is imposed on the model.

\section{(ii) Model 2. Two-locus}

The first locus is assumed to determine susceptibility to the anaesthetic and have two alleles : $\mathrm{n}$ with frequency $\mathrm{q}$ and $\mathrm{N}$ with frequency $\mathrm{p}=1-\mathrm{q}$. The second locus is assumed to be a suppressor locus, also with two alleles : $\mathrm{S}$ with frequency $\mathrm{u}$ and $\mathrm{s}$ with frequency $v=1-u$. Under this model, pigs require two copies of $n$ at the susceptibility locus and at least one $S$ allele at the suppressor locus to be positive reactors. A double dose of $s$ will suppress the reaction in $n n$ pigs. Genotypes $n n S S$ and nnSs are assumed to have the same penetrance (f). The suppressor locus acts as a genetic device removing part of the variation in penetrance as would be observed under the SLR hypothesis.

In general the two loci may be linked and the population may not be in linkage equilibrium. Two types of double-heterozygotes must be recognized : coupling (NS|ns) and repulsion (Ns|nS). With random mating, as in Pietrain-Hampshire, and when linkage disequilibrium $=\mathrm{D}$, the expected genotypic frequencies in the parental group and the corresponding penetrances are shown in Table 1. The conditional probabilities of reactor progeny given the parental genotypes can readily be computed. Thus, for the mating NS|ns $\times$ NS $\mid$ ns $(5 \times 5)$ :

$$
P_{55}=f \theta(2-\theta) / 4
$$


TABLE 1

Genotypic frequencies and penetrances in the two-locus model.

Fréquences génotypiques et pénétrances pour le modèle à deux locus.

\begin{tabular}{c|c|c|c}
\hline \hline Genotype & Code (i) & Frequency & Penetrance \\
\hline NNSS & 1 & $(p u+D)^{2}$ & 0 \\
NnSS & 2 & $2(p u+D)(q u-D)$ & 0 \\
nnSS & 3 & $(q u-D)^{2}$ & $f$ \\
NNSs & 4 & $2(p u+D)(p v-D)$ & 0 \\
NS $\mid \mathrm{ns}$ & 5 & $2(p u+D)(q v+D)$ & 0 \\
Ns $\mid \mathrm{nS}$ & 6 & $2(p v-D)(q u-D)$ & 0 \\
nnSs & 7 & $2(q u-D)(q v+D)$ & $f$ \\
NNss & 8 & $(p v-D)^{2}$ & 0 \\
Nnss & 9 & $2(p v-D)(q v+D)$ & 0 \\
nnss & 10 & $(q v+D)^{2}$ & 0 \\
\hline
\end{tabular}

where $\theta$ is the recombination frequency. The joint likelihood is thus a function of five parameters : $q, v, D, \theta$ and $f$. It is possible to test the hypothesis that the population is in linkage equilibrium $(\mathrm{D}=0)$ and that there is free recombination between the two loci $(\theta=0.5)$. After such restrictions a simpler model is obtained where the joint likelihood is a function of three parameters : $q, v$ and $f$. This will be called the Restricted two-locus model. The SLR hypothesis is obtained when the restrictions $\mathrm{v}=\mathrm{D}=0$ and $\theta=0.5$ are imposed on the model.

TABLE 2

Parameter estimates in Pietrain/Hampshire under Model I (single-locus).

Paramètres estimés en Piétrain/Hampshire avec le modèle $I$ (un seul locus).

\begin{tabular}{l|l}
\hline \hline Gene frequency, $\mathrm{q}$ & 0.61 \\
Penetrance of $\mathrm{Nn}, \mathrm{f}_{\mathrm{l}}$ & 0.00 \\
Penetrance of $\mathrm{nn}, \mathrm{f}_{2}$ & 0.91 \\
\hline
\end{tabular}

In Landrace, where the parental generation was a mixture of subpopulations, the genotypic frequencies can be approximately represented by functions of the mean gene frequencies $(\bar{q}$ and $\bar{v})$, the variances of gene frequencies $\left(V_{q}\right.$ and $\left.V_{v}\right)$ and the covariance 
between allelic frequencies at the two $\operatorname{loci}\left(\operatorname{Cov}_{(\mathbf{q} . v)}\right)$, after assuming equilibrium holds in the different subpopulations. For example, the frequency of NNSS pigs is :

$$
\text { freq }(N N S S)=E\left(p_{i}^{2} u_{i}^{2}\right) \text {; }
$$

after dropping a term involving fourth order moments of differences in gene frequency :

$$
\text { freq (NNSS) } \approx \overline{\mathrm{p}}^{2} \overline{\mathrm{u}}^{2}+\overline{\mathrm{p}}^{2} \mathrm{~V}_{\mathrm{v}}+\overline{\mathrm{u}}^{2} \mathrm{~V}_{\mathrm{q}}+4 \overline{\mathrm{p}} \overline{\mathrm{u}} \operatorname{Cov}_{(\mathrm{q}, \mathrm{v})}
$$

Assuming free recombination between the two loci the joint likelihood in Landrace is a function of six parameters : $\bar{q}, \bar{v}, V_{q}, V_{v}, \operatorname{Cov}_{(q, v)}$, f. The SLR hypothesis is obtained when the restrictions $\bar{v}=V_{v}=\operatorname{Cov}_{(q, v)}=0$ are imposed on the model.

\section{Computations}

A computer program was written to evaluate equation (1) for the different models in this study. The likelihood surface was searched by iteration within the parameter space ; the maximum likelihood was thus located and the co-ordinates of this point provided the ML estimates for the different parameters.

All hypotheses were tested by means of the likelihood ratio (LR) criterion :

$$
\mathrm{LR}=2[\ln (\alpha)-\ln (\beta)]
$$

where $\ln (\alpha)$ and $\ln (\beta)$ are the natural logarithms of the likelihood maxima under the unrestricted and restricted model's respectively. The LR criterion was compared with a $\chi^{2}$ distribution with $\mathrm{n}$ degrees of freedom, $\mathrm{n}$ being the number of parameters on which restrictions were imposed in order to define the null hypothesis.

Approximate confidence regions for some pairs of parameters in the different models were estimated by constructing contour maps of constant values $\gamma$ on the $\log$ likelihood surface such that :

$$
2[\ln (\alpha)-\gamma]=\chi_{2}^{2}=5.99,4.60 \text { and } 3.22
$$

where $\ln (\alpha)$ is the logarithm of the maximum likelohood and the $\chi_{2}^{2}$ values correspond to the $0.05,0.10$ and 0.20 probability levels.

\section{Results}

All likelihood surfaces scanned in the study exhibited a single peak which, in general terms, was always fairly well defined. Figures 1 and 2 illustrate typical likelihood surfaces in Pietrain-Hampshire and in Landrace respectively.

\section{(i) Model 1. Single-locus}

Table 2 shows the parameter estimates under the single-locus model in PietrainHampshire. The estimated penetrance of the heterozygous genotype was 0.00 , which is the value assumed by the SLR hypothesis. Approximate confidence regions are shown in Figures 3 and 4. 


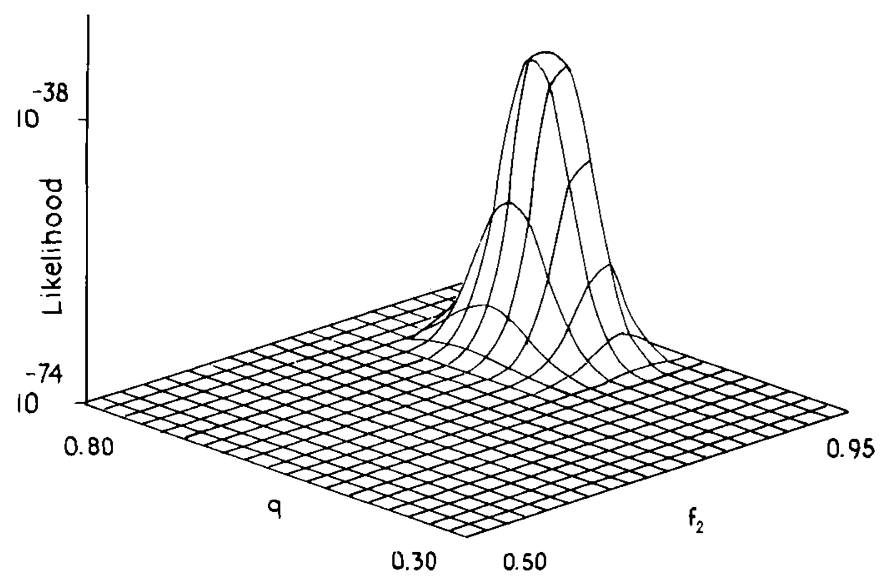

FIG. 1

Likelihood surface for the SLR hypothesis in Pietrain-Hampshire.

Surface de vraisemblance pour l'hypothèse SLR en Piétrain-Hampshire.

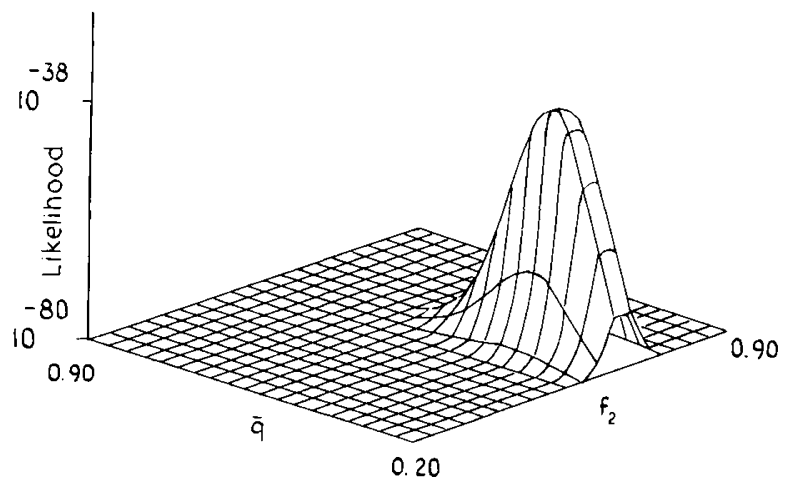

FIG. 2

Likelihood surface for the SLR hypothesis in Landrace. Variance of $q\left(V_{q}\right)$ held at zero.

Surface de vraisemblance pour l'hypothèse SLR en Landrace. Variance de $q\left(V_{q}\right)$ maintenue à zéro.

The results of the single-locus analysis in Landrace are summarized in Table 3. The SLR hypothesis was rejected on the $\chi^{2}$ test $(P<0.01)$ indicating that the addition of a non-zero penetrance for the heterozygotes made a significant improvement in the fit of the model to these data. Approximate confidence regions for the two penetrances are shown in Figure 5. The marked increase in $\mathrm{V}_{\mathrm{q}}$ when moving from the general single-locus model to the SLR hypothesis is to be noticed. This could be interpreted as $\mathrm{V}_{\mathrm{q}}$ conferring some flexibility to an intrinsically inadequate hypothesis. 


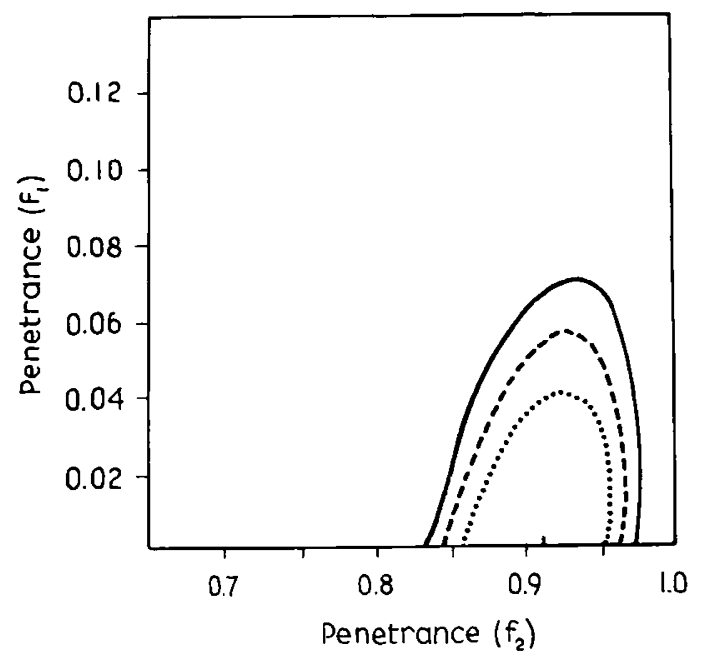

FIG. 3

Contours of constant log likelihood for the single-locus model in Pietrain-Hampshire. representing the approximate $0.05(-), 0.10(-\ldots$,$) and 0.20(\ldots \ldots)$ probability levels. Gene frequency $q$ held at 0.61 .

Contours de valeurs constantes du logarithme de vraisemblance pour le modèle à un seul locus en Piétrain-Hampshire, représentant les niveaux approximatifs $0,05(-), 0,10(--\longrightarrow)$ et $0,20(\ldots \ldots)$ de probabilité. Fréquence q fixée à 0,61 .

TABLE 3

Parameter estimates and differences in log likelihood in British Landrace under Model I (single-locus).

Paramètres estimés et différences en logarithme de vraisemblance en British Landrace avec le Modèle I (un seul locus).

\begin{tabular}{l|c|c|c}
\hline \hline \multicolumn{1}{c|}{ Parameter } & $\begin{array}{c}\text { Single-locus } \\
\text { model }\end{array}$ & $\begin{array}{c}\text { SLR } \\
\text { hypothesis } \\
\mathrm{f}_{1}=0\end{array}$ & $\begin{array}{c}\text { SLD } \\
\text { hypothesis } \\
\mathrm{f}_{1}=\mathrm{f}_{2} \neq 0\end{array}$ \\
\hline Mean gene frequency, $\overline{\mathrm{q}}$ & 0.24 & 0.47 & 0.26 \\
Variance of $\mathrm{q}, \mathrm{Vq}$ & 0.055 & 0.100 & 0.039 \\
Penetrance of $\mathrm{Nn}, \mathrm{f}_{1}$ & 0.22 & - & 0.78 \\
Penetrance of $\mathrm{nn}, \mathrm{f}_{2}$ & 0.91 & 0.67 & 0.78 \\
LR criterion & & 17.22 & 15.57 \\
Probability of greater $\chi_{1}^{2}$ & & 0.00003 & 0.00008 \\
\hline
\end{tabular}




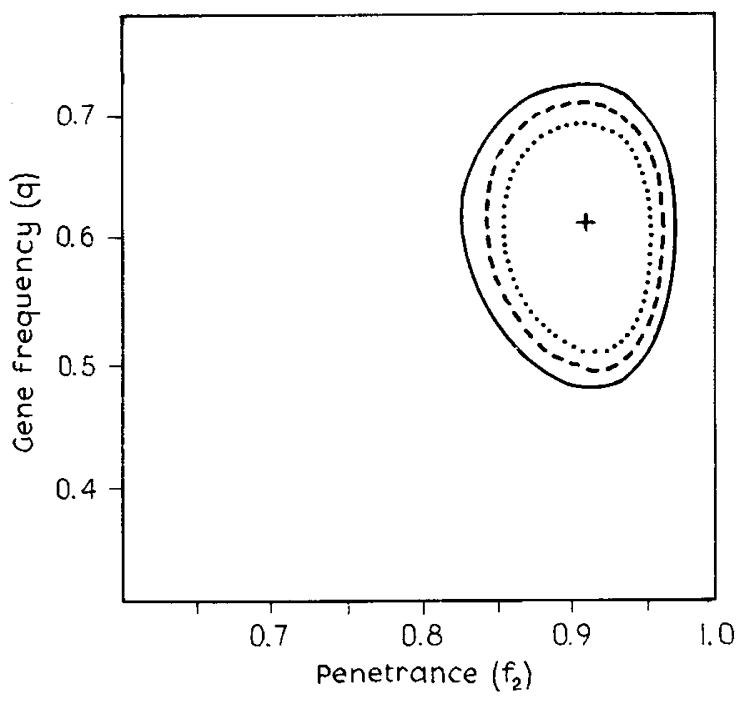

FIG. 4

Contours of constant log likelihood for the single-locus model in Pietrain-Hampshire, representing the approximate $0.05(-), 0.10(\ldots \ldots)$ and $0.20(\ldots \ldots)$ probability levels. Penetrance of $\mathrm{Nn}$ genotypes held at zero.

Contours de valeurs constantes du logarithme de vraisemblance pour le modèle à un seul locus en Piétrain-Hampshire, représentant les niveaux approximatifs 0,05 ( - ), 0,10 (- - - ) et $0,20(\ldots \ldots)$ de probabilité. Pénétrance du génotype $N n\left(f_{l}\right)$ fixée à zéro.

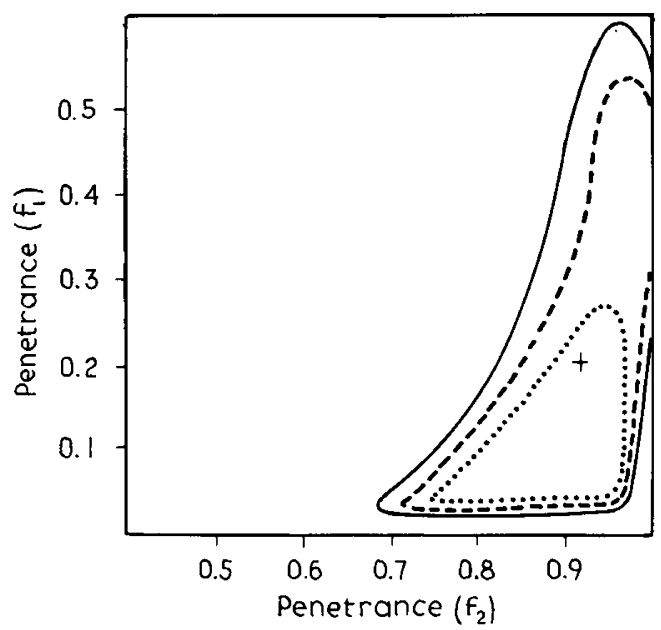

FIG. 5

Contours of constant log likelihood for the single-locus model in Landrace, representing the approximate $0.05(-), 0.10(-\ldots-)$ and $0.20(\ldots \ldots)$ probability levels. Mean gene frequency $\bar{q}$ held at 0.24 . Variance of gene frequency $\left(V_{q}\right)$ held at zero.

Contours de valeurs constantes du logarihme de vraisemblance pour le modèle à un seul locus en Landrace, représentant les niveaux appoximatifs $0,05(-), 0,10(--$, et $0,20(\ldots \ldots)$ de probabilité. Variance de $q\left(V_{q}\right)$ fixée à zéro. 
TABLE 4

Parameter estimates and differences in log likelihood in Pietrain/Hampshire under Model 2 (two-locus).

Paramètres estimés et différences en logarithme de vraisemblance en Piétrain/Hampshire avec le Modèle 2 (deux locus).

\begin{tabular}{l|c|c|c}
\hline \hline \multicolumn{1}{c|}{ Parameter } & $\begin{array}{c}\text { Generalized } \\
\text { two-locus } \\
\text { model }\end{array}$ & $\begin{array}{c}\text { Restricted } \\
\text { two-locus } \\
\text { model } \\
\mathrm{D}=0, \theta=0.5\end{array}$ & $\begin{array}{c}\text { SLR } \\
\text { hypothesis } \\
\mathrm{v}=0\end{array}$ \\
\hline Gene frequency, $\mathrm{q}$ & 0.66 & 0.64 & 0.61 \\
Gene frequency, v & 0.50 & 0.38 & - \\
Penetrance, f & 1.00 & 0.97 & - \\
Linkage desequilibrium, D & -0.034 & - & - \\
Recombination frequency, $\theta$ & 0.50 & 1.72 & $2.26 \dagger$ \\
LR criterion & & 0.42 & $0.13 \dagger$ \\
Probability of greater $\chi_{2}^{2}$ & \\
† SLR hypothesis versus Restricted two-locus model (1 d.f.). \\
\hline
\end{tabular}

TABLE 5

Parameter estimates and differences in log likelihood in British Landrace under Model 2 (two-locus).

Paramètres estimés et différences en logarithme de vraisemblance en British Landrace avec le Modèle 2 (deux locus).

\begin{tabular}{|c|c|c|c|}
\hline Parameter & $\begin{array}{l}\text { Restricted } \\
\text { two-locus } \\
\text { model }\end{array}$ & $\begin{array}{c}\text { SLR } \\
\text { hypothesis } \\
\bar{v}=\mathrm{V}_{\mathrm{v}}=\operatorname{Cov}_{(\mathrm{q} \cdot \mathrm{v})}=0\end{array}$ & $\begin{array}{c}\text { SLD } \\
\text { hypothesis } \overrightarrow{\mathrm{q}}=1, \\
\mathrm{~V}_{\mathrm{q}}=\operatorname{Cov}_{(\mathrm{q} . \mathrm{v})}=0\end{array}$ \\
\hline Mean gene frequency, $\bar{q}$ & 0.63 & 0.47 & - \\
\hline Variance of $\mathrm{q}, \mathrm{V}_{\mathrm{q}}$ & 0.093 & 0.100 & - \\
\hline Mean gene frequency, $\bar{v}$ & 0.67 & - & 0.74 \\
\hline Variance of $v, v_{v}$ & 0.009 & - & 0.039 \\
\hline Covariance $\left(\operatorname{Cov}_{(q, v)}\right)$ & -0.025 & - & - \\
\hline Penetrance, $\mathrm{f}$ & 0.81 & 0.67 & 0.78 \\
\hline LR criterion & & 9.83 & 8.19 \\
\hline Probability of greater $\chi_{3}^{2}$ & & 0.020 & 0.042 \\
\hline
\end{tabular}




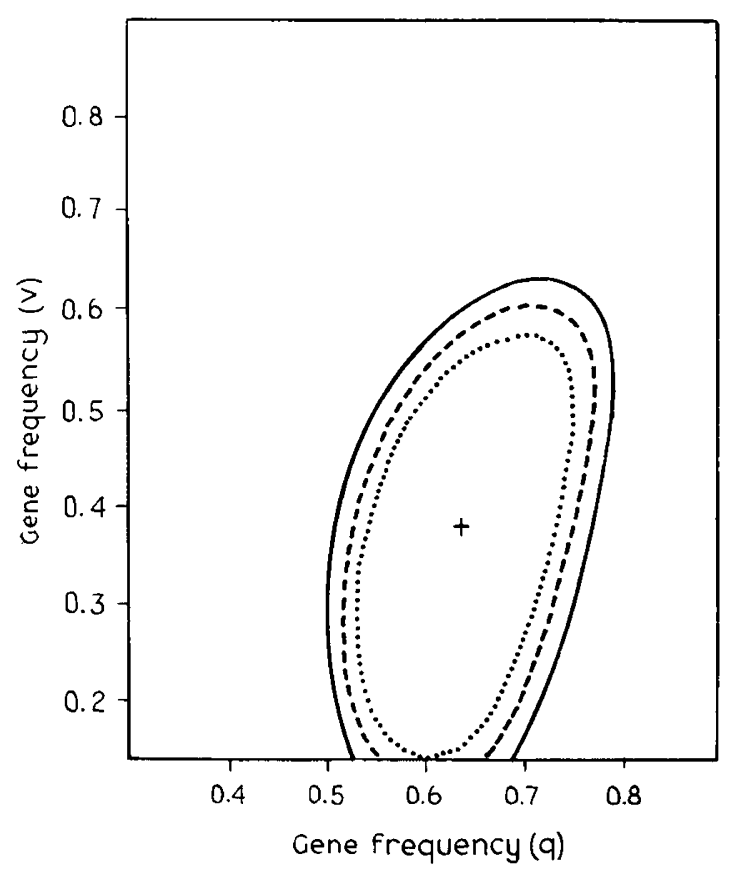

FIG. 6

Contours of constant log likelihood for the restricted two-locus model in Pietrain-Hampshire, representing the approximate $0.05(-), 0.10(-\ldots-)$ and $0.20(\ldots \ldots)$ probability levels. Penetrance $(f)$ held at 0.97 .

Contours de valeurs constantes du logarithme de vraisemblance pour le modèle à deux locus en Piétrain-Hampshire, représentant les niveaux approximatifs $0,05(-), 0,10(---)$ et $0,20(\ldots \ldots)$ de probabilité. Pénétrance $(f)$ fixée à 0,97 .

(ii) Model 2. Two-locus

Table 4 summarizes the analysis under the two-locus model in Pietrain-Hampshire. These was no indication of linkage disequilibrium and its estimate was small, about 20 p. 100 of the maximum disequilibrium possible. The inclusion of these parameters did not improve significantly the fit of the model. The SLR hypothesis was thus tested against the restricted two-locus model ; the LR criterion was 2.26 which is not a very conclusive result for a $\chi_{1}^{2}$ variable. Figure 6 shows the confidence regions for the two gene frequencies under the restricted two-locus model in Pietrain-Hampshire.

The results of the analysis under the two-locus model in Landrace are shown in Table 5. After testing the SLR hypothesis the LR criterion was 9.83 which is statistically significant for a $\chi_{3}^{2}$ variable. Therefore, the SLR hypothesis was also rejected under the two-locus setting $(\mathrm{P}<0.01)$. 


\section{Discussion}

The parameter estimates under the single-locus model in Pietrain-Hampshire differed somewhat from those obtained by SMITH \& BAMPTON (1977). The discrepancy could be due to the fact that only a subset of their data was used in the present study. In agreement with Smith and Bampton the likelihood was maximised when the penetrance of the heterozygotes was equal to zero. These results do not disprove the SLR hypothesis. A different picture emerges from the single-locus analysis in Landrace. The parameter estimates indicate that about a quarter of the heterozygotes were positive reactors after the halothane test. An inspection ot the Landrace data does not reveal a satisfactory fit to the SLR hypothesis. On the one hand there is a deficiency of segregating litters among the negative matings while, on the other hand, there is heterogeneity in the segregation ratios among the progeny from the positive matings, with several families exhibiting what would appear to be very low penetrance values. No such heterogeneity was observed among the positive $\times$ positive matings in PietrainHampshire.

It is possible to test the hypothesis that both heterozygous and homozygous pigs did react to the anaesthetic with equal penetrance; this amounts to testing a singledominant (SLD) hypothesis. As shown in Table 3, the SLD hypothesis was rejected on the $\chi^{2}$ test result. Thus, in contrast to Pietrain-Hampshire, there appears to be a " gene dosage " effect in Landrace whereby carriers of a single copy of the "susceptibility" allele would have a smaller (though non-zero) penetrance than carriers of two copies of such allele. The reasons for this difference between Pietrain-Hampshire and British Landrace are unknown. As the two populations were kept on different farms there could have been differences in relevant environmental circumstances making some of the heterozygous Landrace pigs susceptible to the anaesthetic. However, as little is known about such environmental factors it is difficult to speculate on how a difference might arise. It is possible, though, to conceive a number of genetic explanations. Most of them - such as the presence of more than two alleles at the susceptibility locus or the breeds differing in modifier or suppressor gene frequencies require a broadening of the simple single-locus-two-alleles model favoured so far. The two-locus model in the present study represents one such explanation - not necessarily the most adequate, of course.

Halothane susceptibility thus resembles the " double muscle " trait in cattle in that the mode of inheritance seems to differ between breeds. Under a single-locus hypothesis the "double muscle» trait appears to be recessive in some breeds and dominant in others (Menissier, 1982). Other similarities between these two traits have already been pointed out (Ollivier, 1980).

Although not conclusive, the results of the analysis under the two-locus setting in Pietrain-Hampshire suggest that a model removing genetically part of the variation in "penetrance" could explain the observations better than a single locus with penetrance as a purely environmental parameter. A «mixed model " - a major locus, polygenic variation and environmental effects all contributing to an underlying liability scale with a threshold determining susceptibility (MorTON \& MACLEAN, 1974) - could perhaps perform the task more flexibly. However, it is unlikely that in the present circumstances it would have fitted the data significantly better than the simple two-locus model. 
The two-locus analysis in Landrace also rejected the SLR hypothesis. It is possible to test the hypothesis that :

$$
\overline{\mathrm{q}}=1 \quad \text { and } \quad \mathrm{V}_{\mathrm{q}}=\operatorname{Cov}_{(\mathrm{q}, \mathrm{v})}=0 ;
$$

after such restrictions the two-locus model yields the single-dominant (SLD) hypothesis. The LR criterion indicated that the two-locus model also fitted the data better than the SLD hypothesis $(P<0.05)$. The maximum likelihood obtained under the general singlelocus model was higher than that obtained under the two-locus model. It was not possible to test both models as hypothesis in the same analysis. A general model allowing such a test would have been unwieldy given the structure of the Landrace population.

In summary the SLR hypothesis, favoured so far as the mode of inheritance of halothane susceptibility in pigs, could not be conclusively disproved in PietrainHampshire although there was a suggestion that part of the variation in "penetrance " could be genetically determined. The SLR hypothesis was clearly rejected as the mode of inheritance in British Landrace. It is important to emphazise the fact that the Landrace parents were tested in their original farms ; the varying environmental conditions might have increased the probability of misclassifying the reactions. The lack of matings between reactors and non-reactors and the mixture that constituted the parental group in this breed should also be emphazised. Because of the latter the probability models describing the population required parameters such as variances and covariance of gene frequencies; conclusions of general interest were thus conditional on the value of nuisance parameters in the models. Taking into account all these deficiencies the present findings should be considered as preliminary indications that the generally accepted single and strictly recessive mode of inheritance may not be adequate for the British Landrace breed. Should these findings be confirmed, a unified explanation of the observations in different breeds will probably require a more comprehensive genetic model than a single-biallelic locus. It could be possible to test the hypothesis that penetrance is partly controlled by an autosomal recessive suppressor by intermating non-reactor offspring from reactor $\times$ reactor matings. Among the progeny there should be entire litters of non-reactors (double homozygotes nnss; Table 1). When intermated, these pigs should always breed non-reactors. When mated to reactors they should yield only reactors or reactors and non-reactors in a 1:1 ratio, depending on the genotype of the reactor parent at the suppressor locus.

Received 14 june 1982.

Accepted 20 december 1982.

\section{Acknowledgements}

Thanks are expressed to CONICET and INTA, from Argentina, for financial support to A.E.C., to Professor A. Robertson for valuable suggestions and to Professor J.W.B. KING and $D^{r}$ C. SMITH for discussion. 


\section{References}

Britt B.A., Kallow W., ENDRENYI L., 1978. Malignant hyperthermia-pattern of inheritance in swine. In : Second International Symposium on Malignant Hyperthermia. Ed. : Aldrete J.A. and Britt B.A., New York, Grune and Stratton, pp. 195-211.

Jones E.W., Nelson T.E., Anderson I.L., Kerr D.D., BurnaP T.K., 1972. Malignant hyperthermia of swine. Anaesthesiology, 36, 42-51.

Mabry J.W., Christian L.L., KuHLers D.L., 1981. Inheritance of porcine stress syndrome. J. Hered., 72, 429-430.

McPhee C.P., TAKken A., D'Arcy K.J., 1979. Genetic variation in meat quality and the incidence of malignant hyperthermia syndrome in Large White and Landrace boars. Aust. J. of Exp. Agric. and Anim. Hus., 19, 43-47.

Menissier F., 1982. Present state of knowledge about the genetic determination of muscular hypertrophy or the double muscled trait in cattle. In : Muscle Hypertrophy of Genetic Origin and its Use to Improve Beef Production. Ed. : King J.W.B. and Menissier F., The Hague-Boston-London, The Commission of The European Communities, 387-428.

Minkema D., EIKelendoom G., Van Eldix P., 1976. Inheritance of MHS susceptibility in pigs. In : Proceedings of the Third International Conference on Production Diseases in Farm Animals. Centre for Agricultural Publishing and Documentation, Wageningen, The Netherlands, pp. 203-207.

Morton N.E., Maclean C.J., 1974. Analysis of family resemblance. III - Complex segregation of quantitative traits. Am. J. Hum. Genet., 26, 489-503.

Ollivier L., 1980. Le déterminisme génétique de l'hypertrophie musculaire chez le porc. Ann. Génét. Sél. anim., 12, 383-394.

Ollivier L., Sellier P., Monin G., 1975. Déterminisme génétique du syndrome d'hyperthermie maligne chez le porc de Piétrain. Ann. Génét. Sél. anim., 7, 159-169.

Ollivier L., Sellier P., Monin G., 1978. Frequence du syndrome d'hyperthermie maligne dans des populations porcines françaises; relation avec le développement musculaire. Ann. Génét. Sél. anim., 10, 191-208.

Smith C., Bampton P.R., 1977. Inheritance of reaction to halothane anaesthesia in pigs. Genet. Res.; Cambridge, 29, 287-292.

WebB A.J., 1980 b. The incidence of halothane sensitivity in British pigs. Anim. Prod., 31, 101-105.

Webb A.J., JoRdan C.H.C., 1978. Halothane sensitivity as a field test for stress-susceptibility in the pig. Anim. Prod., 26, 157-168.

Williams C.H., Lasley J.F., Muhrer M.E., Hedrick H.B., 1975. Relationship between fulminant hyperthermia and the porcine stress syndrome. J. Anim. Sci., 41, 261 (abstract).

Williams C.H., Shanklin M.D., Hedrick H.B., Muhrer M.E., Stubbs D.H., Krause G.F., Payne C.G., Benedict J.D., Hutcheson D.P., Lasley J.F., 1978. The fulminant hyperthermia-stress syndrome : genetic aspects, hemodynamic and metabolic measurements in susceptible and normal pigs. In : Second International Symposium on Malignant Hyperthermia. Ed. : Aldrete J.A. and Britt B.A., New York, Grune and Stratton, pp. 113-140. 